\title{
Regionalisation or Regionalism? The Contemporary Legal Status of Cooperation in the South Pacific
}

\section{Introduction}

This article aims to analyse the legal status of regional cooperation among the South Pacific countries and territories, as not every entity in the Pacific Basin possesses the International law features of a state. ${ }^{1}$ Regionalisation, as well as regionalism, as illustrated by the example of the South Pacific region, is a new topic to examine, especially in Polish and European scholarly literature. Therefore, this topic does need further and deeper analysis. First of all, both regionalism and regionalisation are international phenomena that were set against the process of globalisation only in the last two decades of the 20th century. Secondly, the Pacific Ocean became more dominant in geopolitics than the Atlantic Community at the beginning of 21st century. It has to be added that there are many publications regarding local cooperation mechanisms worldwide, but few on the South Pacific itself. Most of them, though, concern political and economic integration, while neglecting the legal aspects of regional integration. ${ }^{2}$

1 In accordance with Montevideo Convention on the Rights and Duties of States from 26 December 1933. The differentiation of the Pacific entities will be described in the further part of this article.

2 Compare: G. Bertram and R.F. Watters, New Zealand and its Small Island Neighbours: A Review of New Zealand Policy toward the Cook islands, Niue, Tokelau, Kiribati and Tuvalu, Victoria University of Wellington, Wellington 1984; R. Crocombe, The South Pacific, University of the South Pacific, Suva 2001; K. Graham, Models of Regional Governance: Sovereignty and the future architecture of regionalism, Canterbury University Press, Christchurch 2008; U.F. Neemia, Cooperation and Conflict: Costs, Benefits and National Interests in Pacific Regional Cooperation, South Pacific Books Ltd, Suva 1986. 
The argumentation in this article will proceed from the following broad issues prior to focusing on the more detailed area of research-Pacific regionalism: What is the nature of regionalism and regionalisation? What forms do they take worldwide? Why do states prefer to cooperate within their regions and not globally? What are the potential benefits of such integration? Why is there a need for such international action? Next, the current state of Pacific regionalisation will be analysed by asking: What forms do regionalism or regionalisation take in the Pacific? What kind of entities (depending on international law status) cooperate with each other in the Pacific? In which areas do the Pacific states integrate at the regional level? What aspects of island states might push them towards regionalism? And finally, are the South Pacific island states able to create a united, integrated region, using the existing legal arrangements?

The Pacific Ocean, being the largest of the Earth's oceanic divisions, is subdivided by the equator into the North Pacific Ocean and the South Pacific Ocean. For the purpose of this article, the term "Pacific" will be used to refer to the English-speaking countries in the South Pacific. The reason for this is that regionalisation is deeper and more complex in Commonwealth countries than in those with French or American connections. Secondly, French and American affiliated countries have colonial or treaty constraints on their ability to participate regionally. Their impact is therefore relatively limited. ${ }^{3}$

The area of research is Pacific island countries divided into three groups: Micronesia, Melanesia, and Polynesia. ${ }^{4}$ However, they are very often engaged in cooperation with the larger, more developed states Australia and New Zealand. For this reason, analysis of the regional cooperation among Pacific states should not be made without consider-

3 This article emphasises international law and regional relations among states. Thus, the intention is not to explore historical or colonial relations between former metropolises and their territories. Only key aspects relating to regionalisation and the regionalism processes of legal subordination will be touched upon.

4 The distinction between those groups of islands was first made by a French explorer, Jules Dumont d'Urville. His purpose was to denote the geographical and ethnic grouping of islands. 
ation of the relations within the neighbourhood. It is necessary to determine both the internal (national) and external (regional) purposes of the Pacific countries in creating a united and prosperous region.

Finally, Pacific regionalism has to be clearly distinguished from two similar areas of cooperation: Pacific Rim and Asia Pacific regionalism. There are 42 sovereign bordering countries ${ }^{5}$ and 23 dependent territories in the Pacific Ocean. Those states are considered to constitute the "Pacific Rim”. The concept of this socioeconomic region reflects the American sphere of interest, and thus is being performed by its educationalresearch organization based in Honolulu, the East-West Center. ${ }^{6}$ As for Asia Pacific regionalism, here the main focus is on the Asian states, including Asian islands, at the same time neglecting islands from the Australian continent. ${ }^{7}$ In other words, the term Asia Pacific is not used to refer to the Oceania islands states very often at all. The author wishes to emphasise in this article that the Pacific is a region that is separate and independent from any other, especially Asia.

\section{Definition of the Key Terms}

The term "region" is derived from a Latin word regio, which means a direction, a location, an area. Additionally, other sources recall the verbs regō - to reign, to govern, to guide, to order, and finally rēgius -

5 The legal status of Taiwan is disputed.

6 The report to the US Congress of. Comptroller General made by E.B. Staats, East-West Center: progress and problems. Report to Congress, 1978, p. 9; The East-West Center and the Pacific, East-West Center, Los Angeles 1985, pp. 3-27.

7 Asia Pacific regionalism will be therefore used as the ground of relations between the biggest economies, like China, Japan, the United States, South Korea and Russia. More on this approach see R. Crocombe, The South Pacific, pp. 601-602; Y. Deng, Chinese Relations with Japan: Implications for Asia-Pacific Regionalism, "Pacific Affairs” 1997, no. 70(3), pp. 373-391; Ch.M. Dent and J. Dosch (ed.), The Asia-Pacific, Regionalism and the Global System, Edward Elgar Publishing Limited: Cheltenham/Northampton 2012; M. Sutton, Open Regionalism and the Asia Pacific: Implications for the Rise of an East Asian Economic Community, “Ritsumeikan International Affairs” 2007, no. 5, pp. 133-152. 
royal. ${ }^{8}$ Consequently, a specified region would be an area separated from its surroundings in the sense of geography, sociology, politics and culture, remaining under legal power. ${ }^{9}$ Another definition refers to an entity formed purely because of the geographical proximity of states. ${ }^{10}$

The question from the title is "regionalisation or regionalism". But there are also similar definitions in the literature describing the process of integration among sovereign states. Collaboration, cooperation and coordination do differ from each other in terms of the scope and extent of partnership: from organisational independence to integration. Integration can be understood as the process of increased intensification of interactions between their participants. ${ }^{11}$ The main purpose of this process is to establish an international community of states which retain selfdetermination in both internal and external matters. To achieve this, the consent of states is needed. ${ }^{12}$ From the normative point of view, the level of decision-making changes from international to supranational. ${ }^{13} \mathrm{Co}-$ operation is the first step in a continuum. It involves a process of sharing expertise and information from entities still possessing an autonomous position from each other. Coordination introduces a higher degree of integration by making mutual adjustment for a better, joint outcome. The

8 P. Wahl, Europejska polityka regionalna, Wyższa Szkoła Integracji Europejskiej, Szczecin 2003, pp. 9, 53.

9 E. Stadtmüller, Regionalizm i regionalizacja jako przedmiot badań naukowych $w$ stosunkach międzynarodowych, in: K. Jędrzejczyk-Kuliniak, L. Kwieciński, B. Michalski, E. Stadtmüller (ed.), Regionalizacja w stosunkach międzynarodowych; Aspekty politycznogospodarcze, Wydawnictwo Adam Marszałek, Toruń 2008, p. 21.

10 Definition by L.J. Cantori and S.L. Spiegel, The International Politics of Regions, Palgrave Macmillan Journals, New Jersey 1973, p. 2.

11 Definition by P.J. Borkowski, Polityczne teorie integracji międzynarodowej, Difin, Warszawa 2007, p. 15.

12 Any forced cooperation would mean forbidden imperial aspirations. Imperialism, especially territorial aggrandisement is forbidden by the norms of modern international law. See Charter of the United Nations (opened for signature 26 June 1945, entered into force 24 October 1945), art. 2(4); W.J. Raymond, Dictionary of Politics: Selected American and Foreign Political and Legal Terms, Brunswick Publishing Corporation, Lawrenceville 1992, Imperialism, p. 228.

13 Stosunki międzynarodowe: geneza, struktura, dynamika, eds E. Haliżak, R. Kuźniar, Wydawnictwo Uniwersytetu Warszawskiego, Warszawa 2006, p. 250. 
next step is collaboration with the most complex degree of integration, leaving some discretion to the entity. In some countries, this concept is referred to by its synonym: partnership. It involves a quasi-formal organisational arrangement for interactions between state (government), society and business.

Regionalism refers to the political idea of forming regions through a formal program:

Regionalism means the body of ideas, values, and objectives that contribute to the creation, maintenance, or modification of a particular region or type of world order. It is usually associated with a formal policy and project and often leads to institution building. Further, regionalism ties agents to a specific project that is limited spatially and socially but not in time. ${ }^{14}$

Regionalism is undeniably connected with regionalisation. Regionalisation refers to the process of region formation, by which regions come into existence and are consolidated as separate entities. ${ }^{15}$ Region formation has to be based on suitable grounds: regional space (set on a particular territory, having its own social identity), regional complex (with trans-local relations), regional society (organised in a formal way), and regional community (a multitude of contacts with shared values and goals). ${ }^{16}$ This process could be characterised by a long-term intensification and deepening of relations, mainly economic, between subjects (namely states) in geographic proximity to each other. Through those economic, social, cultural and political linkages, the whole region becomes intensely correlated. Hence, one can assume regionalisation is perceived as regional cooperation de facto, while regionalism - de iure. ${ }^{17}$

14 International Encyclopedia of Political Science, eds B. Badie, D. Berg-Schlosser, L.M. Badie, SAGE Publications Inc., Los Angeles 2011, Regionalism p. 2244.

15 Ibidem, Regionalization, p. 2246.

16 E. Stadtmüller, Regionalizm i regionalizacja..., pp. 25-26.

17 R. Orłowska, K. Żołądkiewicz, Globalizacja i regionalizacja w gospodarcze światowej, Polskie Wydawnictwo Ekonomiczne, Warszawa 2012, pp. 169-171. 
Regionalisation and regionalism are international phenomena that have been set against the processes of globalisation since the last two decades of the 20th century. Very often, they are opposed to global integration. ${ }^{18}$ Regional cooperation is also seen as an "antidote”, a counterbalance to the negative results of unfair globalisation. Those disadvantages of global integration include: increased consumerism, liberal welfare achieved at the cost of poverty of less developed or prosperous countries or nations, growing inequity between regions, and domestic problems affecting other countries or regions which are not involved directly in the case. ${ }^{19}$ Therefore, regionalisation, along with regionalism, can guarantee more effective cooperation between certain states and local groupings, and a fairer distribution of benefits coming from international trade and the global exchange of goods. ${ }^{20}$

So why do states decide to cooperate with neighbouring countries? Similar legal culture, common traditions, including customary law, the influence of religion, as well as shared history and geopolitical background, persuade governments to enter into close relations locally. States in close geographical proximity have similar problems, aims and needs. Such limitations in managing overall purpose leads to homogeneity, the uniform character of regional organisations, frameworks, forums etc. ${ }^{21}$ Additionally, the aim of every state is to mutually work in the region in order to maximise its own trade and to ensure safety and welfare. The scope of regional interest is manifested by the development of regional communities (regionalisation). This appears through membership and the degree of participation, as well as regional structure building (re-

18 Globalisation as a form of transnational cooperation was widely used, and even abused in many cases, by Europeans during the Age of Discovery in the 15th century. Nonetheless, that is the 19th century, "century of colonization" which can be noted as the beginning of the international order creation.

19 R. Bieniada, Regionalizm i regionalizacja w definicji. Wybrane problemy teoretyczne, “e-Politikon” 2013, no. 6, p. 289.

20 Ibidem, p. 290.

21 J. Klabbers, An introduction to international institutional law, Cambridge University Press, New York 2002, p. 25; J. Menkes, A. Wasilkowski, Organizacje międzynarodowe; Prawo instytucjonalne, Oficyna Wolters Kluwer Polska, Warszawa 2010, p. 76. 
gionalism). Sometimes, one can observe a process of redefining a state's interests, from the national level to the common regional level. ${ }^{22}$ The examples of those state-led regional frameworks are: the Association of Southeast Asian Nations (ASEAN), the African Union (AU), the North American Free Trade Agreement (NAFTA) and the Southern Common Market (MERCOSUR). Next, European integration took deeper legal shape in 1985 through the Single European $\mathrm{Act}^{23}$, harmonising laws in the member states' national orders. ${ }^{24}$

\section{The Main Issues of the Pacific as a Region}

The Pacific region is a unique geopolitical region. However, this is not only due to the diversity of the subjects of international law. The crucial fact seems to be the maritime, oceanic system. Geographical factors have indeed influenced the features of the region, such as social structure, inter-island relations, their national economy, the position among other islands, and possible integration building. Pacific islanders depended on their own resources and inter-island assistance, until colonial times. Even now, they are strongly dependent on foreign aid, in both the political and economic sense.

The analysed region consists of island microstates (also called microeconomies). This implies the necessity of facing some of the challenges associated with being small and remote. But what is more relevant is physical separation from continental lands. There is great dependence

22 The redefinition of national interests can also be made through global partnership. In this case, such rethinking of domestic priorities and partnerships is usually caused by some crucial international factor. See P. J. Borkowski, Polityczne teorie integracji..., pp. 21-22; C. Rice, Rethinking the National Interest: American Realism for a New World, "Foreign Affairs” 2008, July/August.

23 Single European Act signed 17 February 1986 and 28 February 1986, entered into force 1 July 1987, however no longer in force.

24 Ch. Oman, Globalisation and Regionalisation: the Challenge for Developing Countries, OECD, Paris 1994, pp. 34-35; J.U. Wunderlich, Regionalism, Globalisation and International Order: Europe and Southeast Asia, Ashgate Publishing Limited, Aldershot 2007, p. 29. 
on sea and air transport to establish and maintain both domestic and international links. This logistic convenience is visible in every area, such as business, education, medical care, and many other basic needs of islanders. The geographical and economical separation requires frequent interactions with the rest of the world. This in turn results in increased openness to international trade. As a consequence, the Pacific islands have made themselves more exposed to financial flows and possible crises. There are not many instruments to deal with external shock, especially when island states decide to be functionally predicated on independence. Also, small states do not possess a sufficient number of qualified personnel. The human resources in government, administration, education and other vital sectors are lacking. Another aspect of the small population in microstates is difficulties in separating personal, political and institutional interests. ${ }^{25}$ This situation appears at both the local levels of villages and certain islands, but also at the whole state level.

It can be observed that there is a growing awareness of the affiliation to the Pacific by the involvement of many IGOs, NGOs and other non-state institutions acting with the purpose of regional integration. ${ }^{26}$ Loyalties, along with feeling of affiliation to one community, the Pacific community, are very often developed through the family and cultivated at the national level. Islanders regard their states as the basic elements of the Pacific Community. ${ }^{27}$ Participation and further actions through the regional agendas bring an even stronger sense of Pacific identity, while Pan-Pacific feelings are also growing. This affiliation is evident in the increased membership in regional institutions, with their meetings and scholarships across the nations. Therefore, one can observe in this two-way process a kind of "self-driven" regionalism.

25 B. Warner, Caribbean integration - lessons for the Pacific?, Development Policy Centre Discussion Paper 2012/25, Crawford School of Public Policy, Australian National University, Canberra.

26 Those organisations and other ad hoc institutions will be presented in a subsequent part of the article.

27 R. Crocombe, The South Pacific, p. 591. 
"The Pacific Way" is a slogan that emerged to promote the Pacific identity. Another reason was to increase the regional formation in order to create one united region. It was coined by Ratu Sir Kamisese Mara, the first Prime Minister of Fiji in 1970. He is perceived as the most prominent regional leader in the Pacific. His main achievement was to make Fiji the biggest beneficiary of Pacific regionalism. ${ }^{28}$ Nonetheless, the other important outcome of Prime Minister's regional politics was to elaborate the Pacific reputation outwards, and to stimulate regional identity inwards. ${ }^{29}$

\section{Features of Regional Cooperation in the Pacific}

There are three kinds of entities in the Pacific, according to international law: independent states, dependencies and freely associated states ${ }^{30}$. Various legal statuses affect the form and degree of participation in regionalism. Precisely because of that, one needs to be aware of the legal and political modifications among the Pacific countries. Such knowledge will be useful in understanding the areas of potential cooperation and further regional integration. The primary subjects of international law (states) possess a full degree of self-determination and can freely act on both internal and external matters. The other two types of countries (dependent territories and freely associated states) are governed by other states and have to follow their policies. Many dependent territories passed their own legislative acts, which nonetheless have to be in accordance with the acts of their partner states. Also, every island dependency appoints symbols of nationhood, like flags or anthems. From the legal point of view, though, these are not criteria of statehood.

28 Ibidem, p. 157.

29 Interviews made by the author with Prof. Tony Angelo, constitutional lawyer at the Victoria Univeristy of Wellington. He was also a supervisor of the author during her $\mathrm{PhD}$ scholarship in 2015-2016.

30 Resolution defining the three options for self-determination GA Res 1541, XV (1960), Principle VI. 
The subjective scope of the geopolitical region of the South Pacific therefore covers the following: 1) sovereign states: Australia, Fiji, Kiribati, Nauru, New Zealand, Papua New Guinea (PNG), Samoa, Tonga, Tuvalu, Vanuatu, and the Solomon Islands; 2) the associated state with New Zealand: Niue and the Cook Islands; and the associated states with the United States: the Federated States of Micronesia (FSM), Palau and the Marshall Islands; 3) dependencies. From this international legal fact, we can observe that the limited scope of decision-making indeed affects external relations, including regionalism procedures. This also concerns the potential input into the region creation process. More importantly, each island contributes differently to the regional integration processes.

Examples of such limited capacity are numerous, but lay beyond the scope of this article. The membership of dependent territories in IGOs is either impossible or very narrow. The latest illustration of this legal dilemma was the broadening access to New Caledonia and French Polynesia, which were initially granted observer status, and in 2006 associated membership. In 2017 though, there was a huge change as PIF decided to include those two French territories as full members, despite them being non/sovereign states. ${ }^{31}$ The same path applied to Tokelau (in 2005 and 2014, respectively). Currently, the observer status of the Forum is held by Wallis and Futuna, however, the government in Paris is seeking to upgrade this status to associate membership. ${ }^{32}$

The basis for international cooperation can be found in both legal and extrajudicial (extra-legal) norms. The form of unifying standards and mechanisms between states depends only on their will. Therefore, it is states which create a legal order composed of norms of universal, regional or local validity. In line with the system of international law, they bear responsibility for implementation new rules. ${ }^{33}$

31 Pacific Islands Forum Secretariat, Forum Foreign Ministers Meeting - Outcomes, Suva, 11 August 2017.

32 N. Maclellan, France and the Blue Pacific, “Asia \& the Pacific Policy Studies” 2018, no. 5(3).

33 N. Blokker, H. Schermers, Proliferation of International Organizations; Legal Issues, Kluwer Law International, The Hague 2001, pp. 83-84. 
The development of regionalism is taking place mainly through the signing of treaties ${ }^{34}$ and establishing intergovernmental organizations. ${ }^{35}$ Contrary to well-known and primarily used hard law methods, there are also many soft law instruments. The latter are more flexible, easier and desirable for states. Why is that? Governments of certain states might not very often have the intention to formalise and maintain definitive bilateral or multilateral relations. Through international actions, such as signing a treaty, attendance at an intergovernmental conference, participation at international organisations, establishment of diplomatic or consular relations, states impose on themselves international rights and duties. Those duties may be de iure enforced in the future.

Therefore, the facilitation of regional integration is one of the soft law methods employed in the sphere of modern international relations. More importantly, states themselves help to establish entities equipped in those informal mechanisms. Non-binding instruments might de facto ensure a bigger influence than states could exert alone. Thus regional cooperation takes place above all through occasional meetings and regular gatherings of politicians, diplomats, judges and civil servants. Taking advantage of less formal gatherings, or behind-the-scenes talks during official meetings, paradiplomacy appears to be the key form of regional integration. ${ }^{36}$ This is also the case in the Pacific.

There are over 30 regional organizations, the status of which is sometimes hard to ascertain. ${ }^{37}$ They are either IGOs or NGOs, a fact which it will further affect the creation of the possible legal norms for their member states. ${ }^{38}$ Likewise, there are a dozen or so informal regional forums

34 In accordance with the Vienna Convention on the Law of Treaties from 22 May 1969.

35 Therefore, not every regional grouping can be called an international organization.

36 J. Sutor, Leksykon dyplomatyczny, Dom Wydawniczy Elipsa, Warszawa 2010, pp. 99-124;

S. Wolf, Paradiplomacy: Scope, Opportunities and Challenges, “The Bologna Center Journal of International Affairs” 2007, no. 10.

37 According to the author's calculation. The Pacific institutions very often are so informal that they do not create a website or publish any documents after the gatherings.

38 It has to be remembered though that not only a state can become a member of an organization. We can observe the growth of "non-states actors" (NSA) in the 21st century. NSAs become more and more influential. At the same time, the informal character of many ad hoc 
gathering in the Pacific Basin. What seems to be essential here is the fact that the Pacific organizations quite often change their names, due to the expanding scope of their territorial activity, and thus also membership. Additionally, some other regional bodies were incorporated by the largest or newest institutions, which sometimes also broaden their aspects onto more general ones. Consequently, there is the so-called "spaghetti effect” in Pacific regionalism, where singular states are members of numerous formal organizations or informal gatherings, as well as parties to some regional treaties or agreements establishing regional organizations, which at the end become less effective or simply blur in the whole process of regionalisation.

The most important and influential are the following IGOs: Pacific Community, established under the name of the Secretariat of the South Pacific $^{39}$ (SPC) ${ }^{40}$, Pacific Islands Forum (PIF) ${ }^{41}$, and the newest platform - the Pacific Islands Development Forum (PIDF). ${ }^{42}$ Again, they all present the same values of the Pacific Community and humanitarian-economic development, while their members are either the same, or smoothly switch from one to another regional gathering. There are finally subregional organizations: Melanesian Spearhead Group (MSG) ${ }^{43}$, Polynesian Leaders Group (PLG) ${ }^{44}$, and Micronesia Challenge. ${ }^{45}$ How-

types of regional networks, their characteristic pluralism and multidimensionality, give rise to a variety of new entities participating in regionalisation.

39 Due to the political aim of spreading the membership to other countries, also to those from the North Pacific, that is, above the equator, the SPC decided to change its name. Still, it is well-known and recognisable under the old name, as well as its old acronym. The author is in constant collaboration with the Deputy Director-General at the Pacific Community Cameron Diver.

40 Functioning on the legal basis of Canberra Pact: Agreement establishing the South Pacific Commission from 6 February 1947.

41 Agreement Establishing the Pacific Islands Forum from 27 October 2005.

42 Charter of the Pacific Islands Development Forum from 4 September 2015.

43 Agreement Establishing the Melanesian Spearhead Group from 23 March 2007.

44 Memorandum of Understanding Establishing the Polynesian Leaders Group from 17 November 2011.

45 This group does not function as an organization and thus does not have any forming agreement. See The Micronesian Challenge http://themicronesiachallenge.blogspot.com/p/ about.html [access: 20.08.2019]. 
ever, the smaller, grass-rooted initiatives create the potential threat of putting subregional interests over general, regional ones. On one hand, the Pacific region's strength lies in its multiplicity. Sadly, on the other stratification among the Pacific economies is immense and generates even more spheres of interests. ${ }^{46}$

\section{Conclusion}

At the beginning of the 21st century, in the Pacific context, it is highly likely that the contemporary regional cooperation will be sufficient to cope with many of the regions' challenges. Despite the fact that the Pacific states' preferred method of regionalism is working at the level of two Forums - PIF and, since 2015, PIDF $^{47}$, not many regional challenges are being overcome though legally binding measures. Unquestionably, given the Pacific's unique characteristics, the members of regionalisation were, and still are, motivated by the other formal regional groupings, mainly by the EU. Such reorientation was inspired by the European model of common goals: cooperation, harmonisation, and the collaborative use of natural resources. ${ }^{48}$ Those "deep" forms of regionalism, achieved through the increased regional provisions of services and regional market integration, can de facto and de iure create the necessary pool of benefits needed to make regional institutions suitable and beneficial to its members in the Pacific. ${ }^{49}$

46 The poorest extreme is represented by Kiribati, Solomon Islands, Tonga or Vanuatu. M. Jędrusik, Wyspy tropikalne. W poszukiwaniu dobrobytu, Wydawnictwa Uniwersytetu Warszawskiego, Warszawa 2005, p. 143.

47 J. Siekiera, The Pacific Islands Forum 2015, Port Moresby, "New Zealand Yearbook of International Law” 2015, no. 13, p. 147; S. Tarte, A New Regional Pacific Voice? An Observer's Perspective On The Pacific Islands Development Forum, Inaugural Summit, Denarau, Fiji, 5-7 August 2013, "Pacific Islands Brief” 2013, no. 4.

48 T. Angelo, Commentary of the Pacific Islands Forum, "New Zealand Yearbook of International Law” 2005, no. 2, p. 267.

49 Pacific Studies Series, Towards a New Pacific Regionalism, An Asian Development BankCommonwealth Secretariat 2005, p. 52. 
To sum up, in order to answer the question posed in the title of this article, the Pacific is now at the moment of regionalisation, within the process of region development, where the separate entity is being created and is becoming aware of its own uniqueness, potential, as well as obstacles, which can be overcome by the local means and methods. Those economic, social, cultural and political linkages have, since the 1980s, been establishing long-term intensification, and finally erecting the term of "Pacific". Conversely, the South Pacific region is not yet (if ever) at the moment of regionalism. This expected and indeed desired process of region formalization is in the distant future for the small, poor and undeveloped island microstates. They have their own national barriers, including those of a legal nature, and as soon as they manage them, they will be able to build a harmonized legal order at the level of the whole region.

\section{References}

Agreement Establishing the Melanesian Spearhead Group from 23 March 2007.

Agreement Establishing the Pacific Islands Forum from 27 October 2005.

Agreement establishing the South Pacific Commission from 6 February 1947.

Angelo T., Commentary of the Pacific Islands Forum, "New Zealand Yearbook of International Law” 2005, no. 2.

Bertram G. and Watters R.F., New Zealand and its Small Island Neighbours: A Review of New Zealand Policy toward the Cook Islands, Niue, Tokelau, Kiribati and Tuvalu, Wellington 1984.

Bieniada R., Regionalizm i regionalizacja w definicji. Wybrane problemy teoretyczne, “e-Politikon” 2013, no. 6.

Blokker N., Schermers H., Proliferation of International Organizations; Legal Issues, The Hague 2001. 
Borkowski P.J., Polityczne teorie integracji międzynarodowej, Warszawa 2007.

Cantori L.J. and Spiegel S.L., The International Politics of Regions, New Jersey 1973.

Charter of the Pacific Islands Development Forum from 4 September 2015.

Charter of the United Nations from 26 June 1945.

Crocombe R., The South Pacific, Suva 2001.

Deng Y., Chinese Relations with Japan: Implications for Asia-Pacific Regionalism, "Pacific Affairs” 1997, no. 70(3).

Graham K., Models of Regional Governance: Sovereignty and the future architecture of regionalism, Christchurch 2008.

International Encyclopedia of Political Science, eds Badie B., BergSchlosser D., Badie L.M., Los Angeles 2011.

Jędrusik M., Wyspy tropikalne. W poszukiwaniu dobrobytu, Warszawa 2005.

Klabbers J., An introduction to international institutional law, New York 2002.

Maclellan N., France and the Blue Pacific, "Asia \& the Pacific Policy Studies" 2018, no. 5(3).

Memorandum of Understanding Establishing the Polynesian Leaders Group from 17 November 2011.

Menkes J., Wasilkowski A., Organizacje międzynarodowe; Prawo instytucjonalne, Warszawa 2010.

Montevideo Convention on the Rights and Duties of States from 26 December 1933.

Neemia U.F., Cooperation and Conflict: Costs, Benefits and National Interests in Pacific Regional Cooperation, Suva 1986.

Oman Ch., Globalisation and Regionalisation: the Challenge for Developing Countries, Paris 1994.

Orłowska R., Żołądkiewicz K., Globalizacja i regionalizacja w gospodarcze światowej, Warszawa 2012. 
Pacific Islands Forum Secretariat, Forum Foreign Ministers Meeting Outcomes, Suva, 11 August 2017.

Pacific Studies Series, Towards a New Pacific Regionalism, An Asian Development Bank Commonwealth Secretariat 2005.

Raymond W.J., Dictionary of Politics: Selected American and Foreign Political and Legal Terms, Lawrenceville 1992.

Regionalizacja w stosunkach międzynarodowych. Aspekty politycznogospodarcze, eds Jędrzejczyk-Kuliniak K., Kwieciński L., Michalski B., Stadtmüller E., Toruń 2008.

Resolution defining the three options for self-determination GA Res 1541, XV (1960), Principle VI.

Rice C., Rethinking the National Interest: American Realism for a New World, "Foreign Affairs” 2008, July/August.

Siekiera J., The Pacific Islands Forum 2015, Port Moresby, “New Zealand Yearbook of International Law” 2015, no. 13.

Single European Act signed 17 February 1986 and 28 February 1986.

Staats E.B., East-West Center: progress and problems. Report to Congress, 1978.

Stosunki międzynarodowe: geneza, struktura, dynamika, eds Haliżak E., Kuźniar R., Warszawa 2006.

Sutor J., Leksykon dyplomatyczny, Warszawa 2010.

Sutton M., Open Regionalism and the Asia Pacific: Implications for the Rise of an East Asian Economic Community, "Ritsumeikan International Affairs” 2007, no. 5.

Tarte S., A New Regional Pacific Voice? An Observer's Perspective On The Pacific Islands Development Forum, Inaugural Summit, Denarau, Fiji, 5-7 August 2013, "Pacific Islands Brief” 2013, no. 4.

The Asia-Pacific, Regionalism and the Global System, eds Dent Ch.M. and Dosch J., Cheltenham-Northampton 2012.

The East-West Center and the Pacific, East-West Center, Los Angeles 1985. The Micronesian Challenge <http://themicronesiachallenge.blogspot. com/p/about.html>. 
Vienna Convention on the Law of Treaties from 22 May 1969.

Wahl P., Europejska polityka regionalna, Wyższa Szkoła Integracji Europejskiej, Szczecin 2003.

Warner B., Caribbean integration - lessons for the Pacific? Development Policy Centre Discussion Paper 2012/25, Crawford School of Public Policy, Australian National University, Canberra.

Wolf S., Paradiplomacy: Scope, Opportunities and Challenges, "The Bologna Center Journal of International Affairs” 2007, no. 10.

Wunderlich J.U., Regionalism, Globalisation and International Order: Europe and Southeast Asia, Aldershot 2007.

\section{SUMMARY}

\section{Regionalisation or Regionalism? The Contemporary Legal Status of Cooperation in the South Pacific}

This article aims to analyse the legal status of regional cooperation among the South Pacific countries and territories, as not every entity in the Pacific Basin possesses International law features of a state. Regionalisation, as well as regionalism, as illustrated by the example of the South Pacific region, is a new topic to examine, especially in the Polish and European literature. Therefore, this topic does need further and deeper analysis. First of all, both regionalism and regionalisation are international phenomena that were set against the process of globalisation only in the last two decades of the 20th century. Secondly, the Pacific Ocean became more dominant in geopolitics than the Atlantic Community at the beginning of 21st century. There are many publications regarding local cooperation mechanisms worldwide. Most of them, though, concern political and/or economic integration, and neglect the legal aspects of regional integration. The outcome of this article is nonetheless to present the contemporary legal status 
of the South Pacific cooperation, though it is at the stage of regionalisation, while not yet regionalism - fully formalised and structuralised just as it is on the other continents.

Keywords: regionalisation, regionalism, legal status, cooperation, South Pacific, Pacific.

Joanna Siekiera, Faculty of Law, University of Bergen, Magnus Lagabøtes Plass 1, 5010 Bergen, Norway, e-mail: joanna.siekiera@uib.no

DOI 10.14746/ppuam.2020.11.06 